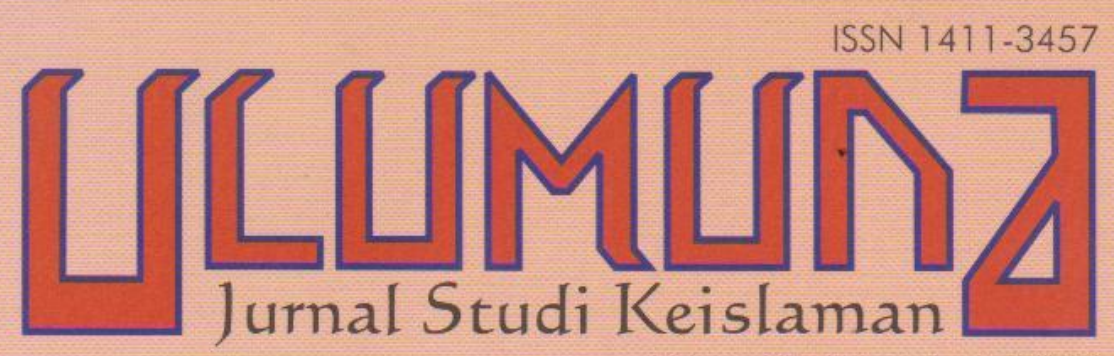

Volume XII• Nomor 1• Juni 2008

STUDI ANALITIS DIMENSI SACIFACT PENDIDIKAN ISLAM PADA MASA KEJAYAANNYA (750-1258 M) Abdul Fattah

AKTUALISASI MANUSIA VERSI AL-QUR'AN: ANTARA IDEALITAS DAN REALITAS PENDIDIKAN ISLAM Ismail Thoib

PENDIDIKAN ISLAM DAN PENCERAHAN SPIRITUALITAS: IKHTIAR MENJAWAB TANTANGAN POSMODERNISME Suparta

LESSON STUDY DALAM PEMBELAJARAN AGAMA ISLAM DI SEKOLAH UMUM Ahmad Munjin dan Khoirul Adib

STUDI PERUBAHAN KELEMBAGAAN DAN METODOLOGI PADA MADRASAH MODEL Taufik Churahman dan Musfigon POSISI PEREMPUAÑ
PERSPEKTIF ULAMA KLASIK
Baehaqi 


\section{PEDOMAN TRANSLITERASI}

\begin{tabular}{|c|c|c|c|}
\hline Arab & Latin & Arab & Latin \\
\hline 1 & $=$ & ف & $=\mathbf{f}$ \\
\hline ب & $=$ & ق & $=\mathrm{q}$ \\
\hline$\dot{H}$ & ts & ك & $=\mathbf{k}$ \\
\hline ج & $=$ & $J$ & $=1$ \\
\hline$\tau$ & $=$ & b & $=\mathrm{m}$ \\
\hline$\dot{\tau}$ & $=\quad \mathrm{kh}$ & $\dot{0}$ & $=\mathbf{n}$ \\
\hline$د$ & $=$ & و - - - 1 & $=\mathbf{w}$ \\
\hline$\dot{j}$ & $\mathrm{dz}$ & • & $=h$ \\
\hline$\jmath$ & $=$ & $\&$ & $=$, \\
\hline j & $=$ & ي & $=y$ \\
\hline س س & $=$ & & \\
\hline ش & $=$ & \multirow{2}{*}{\multicolumn{2}{|c|}{$\begin{array}{l}\text { Untuk Madd } \\
\text { dan Diftong }\end{array}$}} \\
\hline ص & sh & & \\
\hline ض & dl & i & $=$ â (a panjang) \\
\hline b & th & إين & $=\hat{\mathbf{1}}(\mathbf{i}$ panjang) \\
\hline ظ & $\mathrm{zh}$ & أوْ & $=\quad \hat{\mathbf{u}}$ (u panjang) \\
\hline$\varepsilon$ & $=$ & 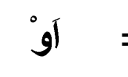 & $=a w$ \\
\hline$\dot{\varepsilon}$ & $=g h$ & آين & $=$ ay \\
\hline
\end{tabular}




\section{ISI}

TRANSLITERASI

ANTARAN

UTAMA

Abdul Fattah

Studi Analitis Dimensi Sacifact Pendidikan Islam pada Masa Kejayaannya $(750-1258 \mathrm{M}) \bullet 1-28$

Ismail Thoib

Aktualisasi Manusia Versi Al-Qur'an:

Antara Idealitas dan Realitas

Pendidikan Islam • 29-46

Suparta

Pendidikan Islam dan Pencerahan

Spiritualitas: Ikhtiar Menjawab Tantangan

Posmodernisme • 47-66

Ahmad Munjin Nasih Lesson Study dalam Pembelajaran

dan Khoirul Adib Pendidikan Agama Islam

di Sekolah Umum • 67-88

Taufik Churahman Dinamika Pendidikan Islam: Studi

dan Musfiqon

Perubahan Kelembagaan dan Metodologi

pada Madrasah Model • 89-106

LEPAS

Mutawalli Pembaruan Hukum Islam:

Menimbang Tawaran Pemikiran

'Abd al-Lâh al-Na'îm • 107-128

Baehaqi Posisi Perempuan

Perspektif Ulama Klasik • 129-142

Ahmad Sulhan Islam Kontemporer: Antara Reformasi

dan Revolusi Peradaban • 143-156

Ahmad Choirul Rofiq Menilai Kompetensi al-Mâturîdî di Bidang

Tafsir al-Qur'an • 157-182

ULAS BUKU

Yayuk Fauziyah Menyingkap Kuasa Maskulinitas di Balik

Tabir Feminitas Wanita Jawa • 183-200

INDEKS 


\title{
ISLAM KONTEMPORER: ANTARA REFORMASI DAN REVOLUSI PERADABAN
}

\author{
Ahmad Sulhan*
}

\section{Abstract}

The $1^{\text {th }}$ and $20^{\text {th }}$ centuries were periods for main transformation in Muslim history: periods of degradation and conquest, independence and revolution, renaissance and reform. Toward the 19th century, world power moved from Muslim world to Europe. It was remarked by emerging power of British, France, Spain, Russia, Netherlands, Italy and Portuguese. They dominated Muslim societies in Asia, Africa, and Middle East in economic, military, politic and ideological aspects. Muslim societies' responses to Europe domination were diverse from rejection and confrontation to emigration and non-cooperative attitudes of traditional Muslim. They planned reform, reconstructed Islamic thinking and beliefs, reformed theology and Islamic law, and emphasized Muslim's self-esteem significance, unity and solidarity in facing cultural threats and Europe colonialism. However, not few secular Muslims and reformers, were proud and greatly imitated Europe civilization and cultures. They did secularization that ended khalifah system in order to reconstruct Muslim societies.

Keywords: Dominasi Eropa, Kolonialisme, Reformasi, Rekonstruksi Pemikiran, Sekularisasi.

TERJADINYA pergeseran kekuasaan dari dunia Islam ke Eropa pada abad XIX telah mengubah hubungan Islam dengan Barat. Kaum muslim harus bertahan menghadapi ekspansi Eropa. Jika tantangan utama terhadap identitas dan kesatuan Islam pada

*Penulis adalah dosen tetap pada Fakultas Tarbiyah IAIN Mataram Jln. Pendidikan 35 Mataram NTB. email: sulhan_smart@yahoo.com 
abad XVIII dan XIX umumnya dipandang sebagai tantangan yang berasal dari intern umat Islam, maka ancaman dari Barat hanya merupakan satu tantangan terhadap politik, ekonomi, moral, dan kebudayaan Islam. Kolonialisme dan imperialisme Eropa telah mengancam sejarah dan identitas politik dan religiokultural Islam. Dengan dimulainya dominasi Eropa terhadap dunia Islam, citra-kalau bukan selalu kenyataanIslam sebagai kekuatan dunia yang ekspansif menjadi hancur.

Peta dunia Islam setelah Perang dunia I menunjukkan besarnya dominasi asing: Perancis di utara, barat, serta daerah Ekuator Afrika, Lebanon, serta Syiria; Inggris di Palestina, Transyordan, Irak, Teluk Persia, dan Anak Benua India; Inggris di Asia Tenggara, Malaysia, Singapura, dan Brunei; dan Belanda di Indonesia. Di Turki dan Iran umat Islam tetap berkuasa, mereka terus-menerus mempertahankan diri terhadap ambisi politik dan ekonomi Inggris, Perancis, dan Rusia yang mengancam stabilitas dan kemerdekaan mereka. Dengan adanya dominasi Eropa dan superioritasnya dalam bidang politik, ekonomi dan militer, maka tidaklah mengherankan jika terjadi transformasi peradaban dari suatu kesemrawutan menuju kemodernan di hampir setiap lini kehidupan masyarakat muslim. ${ }^{1}$

Namun, pandangan kaum Muslim terhadap Barat, baik yang menyangkut kekuasaan serta gagasan-gagasan Barat bermacammacam, mulai dari penolakan dan konfrontasi (didominasi oleh orang-orang Islam tradisional), kekaguman dan peniruan (didominasi oleh para pembaru yang sekular), hingga ke modernisme Islam (penganutnya para modernis yang berusaha menjembatani jurang pemisah antara orang-orang Islam tradisional dengan para pembaru yang sekular). Mereka menggabungkan perhatian masyarakat Islam pada kebangkitan

1John O. Voll, Islam: Continuity and Change in the Modern Word (Colo: Wastview Press, 1982), 3. 
abad XVIII dengan perlunya menanggapi ancaman kolonialisme Eropa dan tuntutan modernitas. ${ }^{2}$

\section{Islam, Kolonialisme Eropa dan Kemodernan: Pembaruan dan Reformasi}

Abad XIX dan XX merupakan periode transformasi utama dan sejarah umat Islam: yaitu periode penghinaan dan penaklukan, kemerdakaan revolusi, serta kebangkitan reformasi. Menjelang abad XIX pergeseran kekuasaan dunia telah bergeser dari dunia Islam ke Eropa yang diwakili dengan munculnya kekuatan Inggris, Perancis, Spanyol, Rusia, Belanda, Italia, dan Portugis. Kekuatan negara-negara Eropa tersebut menguasai masyarakat muslim di Asia, Afrika, dan Timur Tengah, baik di bidang ekonomi, militer, politik, maupun ideologi.

Menghadapi dominasi Eropa, respons yang muncul dari masyarakat Islam tergantung pada sumber ancaman; dari Eropa dan tradisi Islam setempat. Respon tersebut di mulai dari Perang Suci sampai mengadakan imigrasi dan sikap tidak mau berkerjasama dengan kolonial. Penjajahan Eropa menyadarkan masyarakat Islam atas kemundurannya dan memunculkan gerakan kebangkitan serta reformasi. Beberapa pemimpin muslim, mulai dari yang sekular sampai Islam yang modernis, menempuh sikap akomodatif terhadap kekuatan teknologi dan ilmu pengetahuan Barat dalam rangka membangkitkan kembali masyarakat muslim dan meraih kemerdekaan.

"Kebangkitan Islam" (Islamic Revival), muncul dalam berbagai bentuk identifikasi penghayatan dan pengamalan Islam, yang di ikuti dengan pencarian dan penegasan kembali nilai-nilai Islam dalam berbagai aspek kehidupan. ${ }^{3}$ Kemudian menjelma dalam

${ }^{2}$ Albert Hourani, Arabic Though in the Liberal Age (Oxfort: Oxfort Univesity press, 1970), 67.

3John L Esposito, The Islamic Threat Myth or Reality (New York: Oxford University Press, 1992), 7-8. Bandingkan dengan Montgomery Watt, Islamic Fundamentalism and Modernity (London: 1998), 2. 
komitmen yang tinggi-tidak hanya untuk mentransformasi kehidupan individual, tetapi sekaligus kehidupan komunal dan sosial-yang bangkit sebagai reaksi terhadap penetrasi sistem dan nilai sosial, budaya, politik, dan ekonomi Barat, baik sebagai akibat kontak langsung dengan Barat maupun pemikir muslim — tegasnya kelompok modernis, sekularis, dan westernis_atau rezim pemerintah muslim yang merupakan perpanjangan mulut dan tangan Barat.

\section{Respon Modernis: Batasan dan Warisan Modernisme Islam}

Bagi para penguasa di kekaisaran Ottoman (Maroko, Mesir, dan Iran), kekuatan Barat terletak pada teknologi dan persenjataannya yang superior. Para penguasa ini berusaha membuat rakyat mereka sadar akan hal ini. Oleh karena itu, fokus utama mereka adalah penciptaan militer yang kuat dan administrasi yang terpusat. Menghadapi kondisi buruk masyarakat Islam dan tantangan religius serta intelektual Barat, muncul semangat reformasi dari kalangan masyarakat Islam baik yang di Mesir sampai Asia Tenggara. Para modernis Islam di Inggris mencoba menjembatani kesenjangan antara ulama-ulama konservatif dan elit penguasa yang berorientasi Barat.

Di antara tokoh modernis Islam misalnya Jamal al-Din alAfgani (1838-1897) dan Muhammad Abduh (1849-1905), yang merupakan perintis pandangan-pandangan dan agenda modernisasi di Timur tengah. Kemudian Sayyid Ahmad Khan (1817-1897) dan Muhammad Iqbal (1877-1938) di Asia Selatan. Walaupun terdapat perbedaan dalam ide-ide pembaruan mereka, misalnya ada di antara mereka yang menyatakan bahwa agama Islam itu bersifat dinamis dan progresif, namun Islam menjadi mandeg gara-gara perkembangan sejarah dan cara berfikir sebagian besar ulamanya. Mereka menemukan sumber kelemahan umat Islam dalam menegaskan kesesuaian antara agama dengan akal dan ilmu pengetahuan. Sambil menyebutkan 
kejayaan yang pernah diraih ummat Islam di masa lalu, mereka mengingatkan ummat Islam bahwa walaupun mereka saat ini lemah, umat Islam dulu pernah menjadi umat yang kuat. Melahirkan kekaisaran muslim yang luas serta peradaban yang tinggi; meliputi kemajuan di bidang sains, kedokteran, serta filsafat. Para pembaharu muslim itu juga merencanakan cara reformasi mendefinisikan ulang ulang pemikiran dan keyakinan umat Islam, serta mereformasi teologi dan hukum Islam. Pada saat yang sama mereka juga menekankan pentingnya harga diri, persatuan, dan solidaritas di antara umat dalam menghadapi ancaman kebudayaan dan politik kolonialisme Eropa.

\section{Gerakan Nasionalis dan Munculnya Negara Modern}

Paruh pertama abad XX didominasi oleh dua isu yang saling berkaitan, yaitu identitas nasional (nasionalisme) dan kemerdekaan, serta penciptaan negara modern. Gerakan menuntut kemerdekaan dan penciptaan negara modern itu muncul di dunia Islam akibat negatif kolonialisme Eropa, seperti menunjuk pemimpin negara seenaknya, membagi wilayah negara tertentu, serta menciptakan negara baru seperti Yordania. Gerakan menuntut kemerdekaan ini terjadi di beberapa wilayah misalnya: Aljazair, Iran, Afrika Utara, Maroko, Pakistan, serta Tunisia. Umat Islam meningkatkan tekanannya untuk mengakhiri penjajahan Eropa ini antara Perang Dunia I dan Perang Dunia II.

Menjelang 1950-an sebagian besar masyarakat Islam memperoleh kemerdekaannya dan mendirikan negara-negara modern dengan bentuk yang bervariasi. Mustafa Kemal (19231938), yang dikenal sebagai Attaturk, "Bapak Turki," mendirikan negara yang betul-betul sekular, ${ }^{4}$ mengakhiri sistem khilafah,

${ }^{4}$ Kemal Attaturk melakukan sekularisasi yang mengubah bahasa, sejarah, agama, dan politik. Buku-buku yang berbahasa Arab digantikan dengan Inggris, sejarah ditulis ulang, menutup pondok-pondok, melarang 
menggeser institusi-institusi agama dan menggantikannya dengan institusi dan hukum dari Eropa. Di sisi lain, Saudi Arabia diciptakan sebagai negara Islam, dengan menjadikan al-Qur'an sebagai konstitusinya dan syariah sebagai hukumnya. Hampir seluruh negara yang baru merdeka mengambil bentuk negaranya antara negara sekular atau Islam. Sebuah negara akan menjadi "negara Islam" ketika mayoritas penduduknya beragama Islam, dan menerapkan ketentuan-ketentuan Islam dalam sistem ketatanegaraannya, seperti tentang syarat-syarat kepala negara atau menjadikan syari'ah sebagai hukum kenegaraannya. Namun banyak negara Islam, seperti Mesir, Syiria, Iran, dan Irak beralih menerapkan model politik, hukum, ekonomi, dan pengembangan pendidikan dengan mengadopsi khas Eropa.

Antara tahun 1930-1940-an dalam masyarakat muslim muncul dua tokoh terkenal yang memimpin gerakan besar di Timur Tengah dan Asia Selatan. Di antaranya Hasan al-Banna di Mesir yang mendirikan Persaudaraaan Muslim (Ikhwan al-Muslim) dan Maulana Abû al-A'la al-Maududi di India yang mendirikan masyarakat islami (Jama'at al-Islami). ${ }^{5}$ Dua organisasi ini

penggunaan jubah, dan menggantikan lembaga-lembaga tradisional (hukum, pendidikan, dan pemerintahan) dengan yang modern, suatu pilihan yang diilhami oleh Barat. Lihat lebih lanjut; John L. Esposito, Ancaman Islam Mitos atau Realitas, ter. Alwiyah Abdurrahman dan MISSI (Bandung: Mizan, 1996), 90.

5Dua organisasi yang dominan dalam kancah politik Islam abad XX sebagai aktivisme Islam kontemporer yaitu Ikwan al-Muslimin dan Jama'at alIslam. Pendiri dari ideologi keduanya, Hasan al-Banna dan Maulana Abu 'Ala al-Maududi, telah memperlihatkan pengaruh mereka dalam perkembangan organisasi modern Islam di segenappenjuru dunia Islam. Jelas bahwa mereka ini arsitek-arsitek revivalisme yang gagasan serta metodenya dipelajari dan diterapkan mulai dari Sudan hingga Indonesia. Hasan al-Banna (1906-1949) seorang guru dan mantan pengikut tokoh modernis Islam. Rasyid Ridha, mendirikan Ikhwan al-Muslim di Mesir pada 1928. sementara Maulana Abû al-A'la al-Maududi (1903-1979) seorang jurnalis, mengorganisasi Jama'at alIslami di India pada 1941. kedua gerakan ini muncul dan berkembang pada awal tahun 30-an dan 40-an, yakni pada saat masyrakat yang melatar 
mengkritik para elit penguasa yang beriorentasi Barat dan sekular, konservatisme ulama, dan para modernis muslim yang "terbaratkan" berbeda dengan modernis awal, dua organisasi ini menekankan pada kesempurnaan (kemampuan diri) dan mengkritik Barat. Islam, kata mereka, merupakan alternatif yang lebih baik daripada kapitalisme, marxisme, dan sosialisme.

Berbeda dengan para modernis Islam yang lain, al-Banna dan Maududi menekankan pada pengembangan organisasional dalam rangka mewujudkan pandangan mereka tentang masyarakat dan negara Islam. Walaupun mereka berdua dijuluki "fundamentalis" dan dikaitkan dengan pandangan kemunduran, namun kenyataan orientasi dan organisasi mereka adalah modern, mereka juga tidak menolak perkembangan zaman; sains dan pengetahuan modern. Sebaliknya mereka berusaha menyelesaikan ajaran dan nilai Islam dengan (tantangan) dunia modern.

Menjelang akhir 1960-an, nasionalisme Arab dan sosialisme menjadi ideologi utama yang mengantarkan munculnya rezimrezim revolusioner di Mesir, Sudan, Libya, Syiria, dan Irak. Akan tetapi, menjelang akhir 1960-an dan 1970-an beberapa kejadian di dunia Islam memprediksikan yang dialami banyak dunia Islam modern dan masyarakatnya. Kekalahan bangsa-bangsa Arab melawan Israel dalam perang 6 hari di tahun 1967, ditambah dengan hilangnya sejumlah besar wilayah Arab ke tangan Israel (Sinai, Gaza, Tepi Barat, dan Jerusalem), berdampak sangat besar terhadap perkembangan modernisme dunia Islam.

Kegagalan ini memunculkan krisis identitas dalam penduduknya yang sebagian besar beragama Islam, mulai dari Kairo sampai ke Kuala Lumpur. Imbasnya, masyarakat Islam

belakangi kehadiran mereka tertimpa krisis. Keduanya, menganggap imperialisme dan para pemimpin kaum muslim yang telah terbaratkan yang menyebabkan timbulnya berbagai masalah tersebut. Baca, Richart Michell: The Society of Muslem Brother (New York: Oxford Univesity Press, 1969), 104. dan Charles Adams, "Maududi and Islamic State" dalam Voices of Resurgent Islam, ed. John L. Esposito (New York: Oxfort Univesity press, 1983). 
berusaha mencari identitas dengan melihat identitas Islam; sejarah, kebudayaan, dan nilai-nilai Islam pada akhirnya menjadi pilihan mereka.

\section{Relevansi Islam dengan Demokrasi}

Sejalan dengan pilihan Islam sebagai identitas masyarakat Islam, kebangkitan masyarakat Islam termanifestasi dari kehidupan pribadi maupun publik di negara-negara yang mayoritas penduduknya beragama Islam. Kebangkitan Islam ini menampakkan bentuk yang paling nyata dengan berhasilnya revolusi Iran, ${ }^{6}$ yaitu dengan berdirinya negara Islam di bawah kepemimpinan Khomeini. Di negara-negara lain yang mayoritas penduduknya muslim, Islam dijadikan ideologi penguasa untuk memperkuat kekuasaan mereka. Ideologi Islam, simbol-simbol, retorika, partai politik, dan organisasi islami menjadi gambaran umum di masyarakat muslim. Misalnya pemimpin Libya Muammar al-Qaddafi, dan pemimpin Sudan, Ja'far Muhammad

${ }^{6}$ Keberhasilan revolusi Iran memesonakan dunia Islam dan mempengaruhi aktivis-aktivis Muslim di seluruh dunia, setelah revolusi, delegasi-delegasi pemimpin Islam berdatangan dari Amerika Utra, Timur Tengah, dan Asia ke Teheran untuk mengucapkan selamat kepada Khomaeni. Para aktivis organisasi Syi'ah maupun Sunny mulai dari Mesir (Ikbwan al-Muslimin yang moderat dan Al-jihad yang radikal) sampai ke Malaysia (ABIM atau Gerakan Pemuda Malaysia, dan PAS militan) mendapat inspirasi yang diberikan oleh Iran. Revolusi Iran memberikan pelajaran "untuk membangkitkan orang-orang muslim dan mengembalikan kepercayaan diri mereka dalam agama, sehingga mereka dapat lagi memimpin dunia dan menempatkan dunia di bawah naungan peradaban Islam yang mulia." Revolusi Iran menjadi pengingat bahwa Islam menjadi jalan hidup yang komprehensif yang mengatur tatacara ibadah dan masyarakat: "Islam adalah agama dan negara, pemerintah dan politik, organisasi ekonomi dan sosial, pendidikan dan moral, ibadah dan jihad." Baca John L. Esposito dan John O. Voll, Demokrasi di Negara-Negara Muslim: Problem dan Prospek, ter. Rahmani Astuti (Bandung: Mizan, 1999), 66-100; dan John J. Donouhue and Jonhn L. Esposito (ed.), Islam In Trastition: Muslim Perspectives (Oxford: Oxford University Press, 1982), 247. 
Numayri yang pada mulanya seorang sosialis, akhirnya merubah ideologi pemerintah mereka menjadi ideologi Islam; Numayri dengan "way the Islamic way" nya" dan Qaddafi dengan "Green Book"nya. ${ }^{8}$

Selama tahun 1970-an dan 1980-an, Islam terbukti menjadi sumber efektif bagi gerakan oposisi dan protes di beberapa negara Islam: Iran, Pakistan, Afghanistan, Mesir dan Libanon. Simbol-simbol, slogan-slogan, pemimpin agama, ideologi, organisasi, dan institusi islami memainkan peran penting dalam mengorganisasi dan memobilisasi massa. Tahun 1980-an mayoritas negara Islam di perintah penguasa otoriter dengan dukungan kekuatan tentara khusus dan militer. Beberapa negara mungkin memiliki parlemen dan partai politik, namun umunya mereka berada di bawah kontrol penguasa atau partainya. Walaupun beberapa negara muslim telah mengadakan pemilihan

${ }^{7}$ Sebuah buku undang-undang yang ditulis Numayri yang secara resmi di umumkan pada 8 September 1983, kemudian dikenal dengan "UndangUndang September," berisi tentang semakin di tekannya Islam olehnya, yang menyerukan penerapan hukum Islam yang akan mempengaruhi politik hukum dan masyrakat Sudan. Pendekatan Numayri dan masyrakat Islam mempunyai keterkaitan dengan karakter Islami sejarah politik dan kebudayaan Islam masyrakat Sudan. Karena itu, ia yakin bahwa ia mempunyai kemampuan untuk mengkonsolidasikan dukungan umat di kalangan penduduk Sudan yang 70 persen muslim walaupun hal itu mengancam akan mengalienasikan orang-orang Kristen dan kaum Animis di bagian selatan. Lihat Esposito dan Voll., Demokrasi...., 122-9.

${ }^{8}$ Buku hijau memperjuangkan banyak tema yang umum bagi nasionalisme Arab dan pemikiran Islam Kontemporer: Anti-Kolonialisme dan anti-Imprealisme, bergantung pada Barat merupakan sumber kelemahan dan hilangnya identitas muslim, ketidakadilan sosial telihat dari adanya eksploitasi dan korupsi., kembalinya Islam untuk memulihkan kekuatan dan kebesaran Arab/muslim. Qaddafi menyerukan agar kembali ke Islam yang memberikan bimbingan yang menyeluruh bagi manusia: "kita harus memusatkan perhatian pada al-Qur'an dalam perjalanan bidup kita, kaerna al-Qur'an itu sempurna; disitulah terletak cahaya dan pemecahan semua problem manusia, dari status pribadi ke masalab-masalah internasional”. Lihat Esposito, Ancaman..., 93-4. 
umum, tapi militer tetap memiliki pengaruh penting dalam politik negara tersebut.

Pada akhir 1980-an dan awal 1990-an, beberapa kejadian penting telah menyebabkan munculnya sistem politik yang terbuka di negara-negara Islam (demokratisasi dan liberalisasi politik). Salah satu sebab utama perubahan ini adalah terjadinya krisis ekonomi dan pangan, disusul dengan jatuhnya Uni Soviet, liberalisasi di Eropa Timur, dan Perang Teluk. Negara-negara yang merubah sistem politiknya menjadi terbuka antara lain adalah Mesir, Tunisia, Jordan, Pakistan, dan Aljazair. Saudi Arabia, yang pada awalnya tidak bersedia menciptakan lembaga perwakilan rakyat, akhirnya bersedia membentuk badan pertimbangan (Majlis Syura) walaupun anggota-anggotanya di tunjuk oleh raja sendiri, bukan hasil pemilihan rakyat.

Secara teoretis, persoalan demokrasi bagi masyarakat muslim juga menjadi perdebatan yang hangat: apakah ia sesuai dengan Islam atau sebaliknya? Terdapat dua arus yang berbeda dalam menghadapi persoalan ini: menolak demokrasi karena dianggap tidak sesuai dengan Islam dan menerima demokrasi karena tidak bertantangan dengan ajaran Islam. Syaikh Fadlallah Nuri dari Iran, Sayyid Quthb, serta Abu al-'Ala Maududi termasuk dalam kelompok pertama. Sedangkan yang termasuk dalam kelompok kedua antara lain kelompok Hizb al-Nahda dari Tunisia, dan Ali al-Abbasi al-Madani pemimpin FIS ${ }^{9}$ di Aljazair.

Seiring perjalanan waktu, banyak umat Islam yang telah menerima konsep demokrasi, walaupun dengan pemahaman yang berbeda-beda: ada yang memahaminya sebagai lembaga syura, dan yang lain menekankan aspek/ijtihad dan ijma'

9Partai Oposisi Islam di Aljazair. Nama partai ini adalah Aljabhatu alIslamiyatu Li al-Inqadh (Front Keselamatan Islam), yang akronimnya dalam bahasa Perancis adalah FIS (Front Islamiquedu Salut). FIS adalah sebuah organisasi payung atau koalisi yang di dirikan pada 1981 di bawah pimpinan syaikh Ali Abbasi Madani (1931), seorang profesor moderat berpendidikan agama dan Barat di Univesitas Aljazair. 
(konsensus). Namun secara umum majlis syura dianggap sebagai bentuk demokrasi yang tepat dalam Islam, dengan tetap mengakui perbedaan esensial antara demokrasi Barat dengan demokrasi dalam Islam terkait dalam aspek kedaulatan. Demokrasi Barat meletakkan kedaulatan rakyat di atas segalanya, sedangkan demokrasi Islam menganggap kedaulatan Tuhan (wahyu: syari'ah) yang harus di posisikan sebagai yang tertinggi.

\section{Isu dan Prospek Masa Depan Islam}

Sejarah masyarakat Islam abad XXI menampakkan periode transformasi besar-besaran di bidang agama, politik, dan sosial. Di tengah-tengah banyaknya isu dan kejadian, muncul pertanyaan mendasar berkaitan dengan hasil ijtihad ulama masa lalu dan kewenangannya. Di antara pertanyaan-pertanyaan itu antara lain: siapakah di antara mereka yang memelihara Islam? dan apakah Islam itu? Dua pertanyaan ini timbul pada titik waktu antara tradisi dan modernitas, sebab masyarakat muslim kontemporer menggabungkan kehadirannya bersama dan saling mempengaruhi terhadap masa lalu, masa kini, dan masa depan.

Pertanyaan pertama, "Siapakah yang memelihara Islam"? Secara historis, para penguasa (sultan dan khalifah) adalah pelindung Islam, dan ulama adalah penjaga penafsir Islam. Pada paruh kedua abad XXI, para penguasa dan pelindung Islam nampak lebih variatif, mulai dari raja, pemimpin militer, mantan pemimpin militer yang menjadi penguasa dan pemimpin agama. Para ulama pun juga memainkan peran yang signifikan di dunia Islam modern, seperti Ayatullah Khomeini di Iran, Imam Musa Sadr di Lebanon, dan Abu al-Qasim Khoi di Irak. Para pemikir non-ulama juga memainkan peran penting dalam menjaga Islam, di antaranya Jamal al-Din al-Afghani, Muhammad Iqbal, Moh. Natsir, Hamka, dan M. As'ad. Mereka menghasilkan banyak tulisan dalam berbagai bidang ajaran Islam.

Pertanyaan kedua adalah "Apakah Islam itu"? Apa interpretasi terhadap Islam? Islam, seperti tradisi keagamaan 
yang lain, merupakan objek interpretasi historis manusia, -sesuai dengan konteks masa yang berlaku isu kunci yang terkait dengan masalah ini adalah hubungan antara tradisi dan modernitas atau posmodernitas, apakah proses islamisasi harus didasarkan pada doktrin Islam klasik ataukah memformulasikan respons baru (dengan tetap berdasarkan al-Qur'an dan hadis) terhadap tantangan zaman yang isunya cepat berubah kemudian tidak terfokus pada perubahan, tetapi pada sejauhmana perubahan itu dilakukan terhadap doktrin Islam klasik menghadapi permasalahan ini. Menjawab pertanyaan ini, terhadap empat orientasi jawaban dari kalangan pemikir muslim; sekular, konservatif (atau tradisional) neorevivalis (atau fundamentalis) dan neomodernis.

\section{Analisa Kritis kemunduran Islam dan respon Terhadap Kemajuan Barat}

Secara historis, pada masa kejayaan politik muslim, khususnya di masa Dinasti Usmani, perasaan "kemadanian" (sufficienci) kaum muslim terhadap Islam begitu tinggi sehingga mereka lalai mencermati perkembangan dan dinamika masyarakat non-muslim, dalam hal ini Eropa. Kaum muslim merasa tidak perlu mengamati apalagi belajar dari kaum kafir, karena Islam diyakini "memadai" untuk menjawab tantangan orang-orang kafir tersebut. ${ }^{10}$ Sementara pada pihak lain, Eropa terus mengembangkan sains yang mereka transmisikan di kawasan Islam. Dengan kemajuan dicapainya, Eropa semakin memainkan peran penting dalam peristiwa-peristiwa yang menentukan (Indeterminis events) pada tingkat global.

Esensi kekuatan Barat terletak pada konsep dan institusi modern yang dalam banyak hal terlepas dari agama. Karakter khas kekuatan Eropa inilah yang selanjutnya menimbulkan

${ }^{10}$ Azyumardi Azra, Pengelolaan Politike Islam: Dari Fundamentalisme, Modernisme, Hingga Post Modenisme (Jakarta: Paramadina, 1996), vi. 
semacam "kecanggungan" di kalangan para pembaru muslim ketika mereka mencoba merumuskan respons mereka terhadap tantangan Eropa dan dunia modern. Respons itu dapat dikelompokkan menjadi tiga bentuk pendekatan; yaitu pendekatan apologetik, identifikatif, dan affirmatif.

Melalui pendekatan apologetik sebagian pemikir muslim mengemukakan kelebihan-kelebihan Islam tidak hanya untuk menjawab hegemoni politik Eropa, tetapi sekaligus tantangan intelektual Eropa. Sikap apologetik pada batas tertentu bisa dipahami dan dibenarkan, bahkan dibutuhkan dalam upaya membangkitkan rasa kebanggaan kepada ajaran Islam dan sejarahnya yang pernah jaya. Tetapi harus segera diakui bahwa sikap apologis sering tidak memecahkan masalah, karena ia tidak memberikan jawaban yang konkret terhadap tantangan yang ada. Apologis hanya akan melumpuhkan pemikiran kreatif untuk menjawab berbagai tantangan yang ada.

Pada pihak lain pendekatan identifikatif diambil untuk mengidentifikasi masalah-masalah yang dihadapi guna merumuskan respon dan sekaligus identitas Islam di masa modern. Pendekatan identifikatif nampaknya lebih membuka peluang bagi kemunculan pemikiran dan usaha kreatif dan proaktif yang bersifat problem solving. Sedangkan pendekatan affirmatif dilakukan untuk menegaskan kembali kepercayaan kepada Islam dan sekaligus menguatkan kembali eksistensi masyarakat muslim itu sendiri.

\section{Catatan Akhir}

Walaupun reformasi Islam modern seringkali dihadirkan sebagai sebuah jawaban terhadap tantangan Barat, namun sesungguhnya hal itu berakar pada Islam (tradisi kebangkitannya) dan Barat (tanggapan terhadap kolonialisme Eropa). Selama berabad-abad, para ahli teologi, hukum, tasawuf, dakwah, dan organisasi-organisasi pembaruan Islam terus melakukan 
pembaruan dalam rangka menggapai jurang pemisah antara ideal Islam dan kenyataan hidup kaum muslim.

Di samping itu, munculnya gerakan pembaruan dalam Islam karena terpengaruh terhadap persepsi mereka akan "sukses Barat" sebagai bangsa yang kuat dan berhasil; memiliki keunggulan di bidang politik, ilmu pengetahuan, dan kebudayaan, sehingga mereka percaya bahwa sumber kekuatan Barat harus diakomodasi dan diasimilasi. Wa Allâh 'alam bi alshawâb.

\section{Daftar Pustaka}

Albert Hourani, Arabic Thougt in The Liberal Age (New York: Oxford univesity Press, 1969).

Azyumardi Azra, Pergolakan Politik Islam: Dari Fundamentalisme, Modernisme Hingga Post Modernisme (Jakarta: Paramadina, 1996).

Carles Adam, "Maududi and Islamic State," dalam Voices Of Resurgent Islam, ed. John L. Esposito (New York: Oxford Univesity Press, 1983).

John J. Donohue and John L. Esposito (ed.), Islam in Transition: Muslim Perspectives (New York: Oxfort University Press, 1982).

John L. Esposito, The Islamic Threat: Myth or Reality (New York: Oxford Univesity Press, 1992). , Ancaman Islam Mitos atau Realitas, ter. Alwiyah Abdurrahman dan MISSI (Bandung: Mizan, 1996).

John O. Voll, Demokrasi di Negara-Negara Muslim: Problem dan Prospek, ter. Rahmani Astuti (Bandung: Mizan, 1999). , Islam: Continuity and Change in the Modern World (Boulder Colo: Westview Press, 1982).

W. Montgomery Watt, Islamic Fundamentalizm and Modernity (London: t.n.p, t.t., 1998). 